\title{
Milk ELISA in Diagnosing Paratuberculosis in Cattle and Buffaloes
}

\author{
Deepti Narang*, Gagandeep Kaur, Sumiyah Rasool, Mudit Chandra and N.S. Sharma
}
Department of Veterinary Microbiology, College of Veterinary and Animal Science, Guru Angad Dev Veterinary and Animal Sciences University, Ludhiana, Punjab, India
*Corresponding author

\begin{tabular}{|c|c|}
\hline \multicolumn{2}{|r|}{ A B S T R A C T } \\
\hline & \multirow{7}{*}{$\begin{array}{l}\text { Paratuberculosis or Johne's disease is a chronic debilitating disease of ruminants caused by } \\
\text { Mycobacterium avium paratuberculosis. In dairy cows, paratuberculosis has been } \\
\text { associated with production losses such as decreased milk yield, pre-mature culling, } \\
\text { reduced carcass value etc. A possible mode of transmission for the ruminant pathogen } \\
\text { Mycobacterium avium subsp. Paratuberculosis (MAP) from cattle to humans is via milk } \\
\text { and dairy products. Although, MAP has been suggested as the causative agent of Crohn's } \\
\text { disease and its presence in consumers' milk might be of concern. During the active stage of } \\
\text { infection and prior to the onset of clinical disease, animals generally develop antibodies to } \\
\text { MAP antigens. Uninfected animals lack specific antibodies to MAP. In this study a total of } \\
128 \text { milk samples from cattle and buffaloes (irrespective of shedding of acid fast bacilli in } \\
\text { the faeces) were screened for the presence of antibodies against MAP. A commercially } \\
\text { available in vitro diagnostic kit for detection of antibodies against MAP was used. Seven } \\
\text { out of } 128 \text { milk samples (5.46\%) were positive by ELISA. The percent positivity of }>15 \% \\
\text { was considered as positive sample. The percent positivity of positive control was } \\
\text { considered as } 100 \% \text {. The percent positivity ranged from } 20 \% \text { to } 100 \% \text {. However, none of } \\
\text { the milk sample was positive for the presence of MAP by using conventional PCR and real } \\
\text { time PCR using Taq Man assay. The presence of MAP specific antibodies in the milk is an } \\
\text { indication of prior exposure of the animal to the organism. }\end{array}$} \\
\hline & \\
\hline $\begin{array}{l}\text { Mycobacterium avium } \\
\text { subsp. } \\
\text { paratuberculosis, } \\
\text { ELISA, Jhone's } \\
\text { disease. }\end{array}$ & \\
\hline Article Info & \\
\hline & \\
\hline $\begin{array}{l}\text { Available Online: } \\
10 \text { November } 2017\end{array}$ & \\
\hline & \\
\hline
\end{tabular}

\section{Introduction}

Mycobacterium avium subsp. paratuberculosis (MAP), the recognized pathogen of Johne's disease (JD), causes chronic granulomatous enteritis in cattle, sheep and other ruminants (Beard et al., 2001) and results in significant economical loss to the dairy industry (Ott et al., 1999). It has also been suspected as a causative agent of Crohn's disease in humans (Hermon et al., 2000). Given its global coverage, it was included by the World Organisation for Animal Health (OIE 2004) in the list of diseases with particular economic importance and importance for public health (OIE, 2008). Johne's disease occurs in the majority of European countries (Nielsen and Toft, 2009), in both Americas (Manning and Collins, 2001; Hori-Oshima et al., 2007), Asia (Singh et al., 2008) as well as in Australia and New Zealand (Ridge et al., 2010).

The 'gold standard' for Mycobacterium avium subsp. paratuberculosis identification is still based on bacterial culture on solid media of 
faecal samples (Ayele et al., 2001). The slow growth (up to 16 weeks) and false negatives in samples that have low concentrations of MAP makes it difficult to implement efficient protective strategies in an animal population when the MAP identification is solely based on bacterial cultivation (Collins, 1996). Due to the chronicity and preclinical nature of the disease, no single assay at a time will be able to detect all infected cows within a herd (Kalis et al., 2003).

Furthermore, even when more sensitive molecular assays are used, fewer than one third of infected preclinical cows in a herd will be identified (Whitlock, 2009). Several diagnostic tests involve detection of an immune response to the bacteria, with ELISA being most commonly used. ELISA kits can be used to detect a quantitative optical density (OD) reading that correlates to the amount of MAP-specific antibody in milk samples (Nielsen, 2010).

ELISA is a much more time and cost-efficient assay than direct pathogen detection methods. However, sensitivity of ELISA is generally poor ( 29 to $61 \%$ ), with specificity between 83 to $100 \%$ (Nielsen and Toft 2008). Efforts have been made in the last few decades to develop protocols for the detection of MAP in feces milk, tissue, food and environmental samples using various methods. Serology and fecal culture, however, are the most commonly used tests in the field (Stable $e t$ al., 2002). Polymerase chain reaction (PCR) is an ideal method for rapid and accurate detection (Vander Giessen et al., 1992).

Progress has been made recently to improve the sensitivity of PCR-based tests for MAP in milk (Gao et al., 2007). The present study was planned with an objective to detect antibodies against Mycobacterium avium subsp. paratuberculosis in bovine milk samples using ELISA.

\section{Materials and Methods}

\section{Collection of samples}

Milk samples $(n=128)$ from cattle and buffaloes (irrespective of shedding of acid fast bacilli in the faeces) with a history or incidence of chronic intermittent diarrhoea from dairy farms in and around Ludhiana were screened for the presence of antibodies against Mycobacterium avium subsp. paratuberculosis. The samples were refrigerated at $4^{\circ} \mathrm{C}$ until further use.

\section{Microscopic examination of milk samples}

Milk samples were also subjected to acid-fast staining. $5 \mathrm{ml}$ of the pooled milk was centrifuged at $2500 \mathrm{rpm}$ for 15 minutes and the supernatant was discarded. Smear was prepared from the pellet collected at the bottom of centrifuge tube. The smear was then stained with Ziehl Neelsen Staining.

\section{Isolation of DNA from milk samples}

DNA was extracted from milk using MagaZorb®DNA Mini-Prep Kit (Promega).

\section{IS900 PCR}

DNA was amplified by PCR using Primers based on IS900 sequence (Table 1). For the amplification of the IS900 sequence a ready to use GoTaq ${ }^{\circledR}$ Green Master Mix, 2X (Promega) (that contains GoTaq ${ }^{\circledR}$ DNA Polymerase, $400 \mu \mathrm{M}$ of each dNTPs, $3 \mathrm{mM}$ $\mathrm{MgCl}_{2}$ and two dyes (blue and yellow) that allow monitoring of progress during electrophoresis) was also used. For this the reaction volume of $25 \mu \mathrm{l}$ was made containing $12.5 \mu \mathrm{l}$ of GoTaq ${ }^{\circledR}$ Green Master mix, $1 \mu 1$ of forward primer $(10 \mathrm{pmol} / \mu \mathrm{l}), 1 \mu \mathrm{l}$ of reverse primer $(10 \mathrm{pmol} / \mu \mathrm{l}), 0.5 \mu \mathrm{l}$ of nuclease free water and $10 \mu 1$ of DNA template. Along with the test sample DNA, a known positive 
control DNA was also amplified. Thermal cycling were performed in research thermal cycler (Eppendorf, Germany) and cycling conditions were as follows, initial denaturation at $94^{\circ} \mathrm{C}$ for $3 \mathrm{~min}$, followed by 40 cycles of denaturation at $94^{\circ} \mathrm{C}$ for $45 \mathrm{sec}$, annealing of primers at $56^{\circ} \mathrm{C}$ for $45 \mathrm{sec}$, extension at $72^{\circ} \mathrm{C}$ for $45 \mathrm{sec}$ and final extension at $72^{\circ} \mathrm{C}$ for $10 \mathrm{~min}$. PCR products were run by agarose gel electrophoresis and visualized in Gel Documentation System (Alpha Innotech).

\section{IS900MAP TaqMan Real-time PCR Assay}

TaqMan real-time PCR assay for this study was done for the detection of Mycobacterium avium subsp. paratuberculosis. The MAP specific sequence $I S 900$ was targeted as this sequence is having the highest copy number. Primer and probe sequences used in the assay are given in Table 2 . The probe was labeled with the fluorescent reporter dye 5carboxyfluoroscein (FAM) on the 5 end and the quencher dye $N_{-}, N_{-}, N_{-}, N_{-}$-tetramethyl-6carboxyrhodamine (TAMRA) on the 3 end. Primers and probes specific for MAP IS900sequence DNA were obtained from Applied Biosystem.

\section{ELISA testing}

The milk samples were subjected to ELISA using an invitro diagnostic kit (Prionics, based on EIA) for detection of antibodies against Mycobacterium avium paratuberculosis. The absorbance was read at $450 \mathrm{~nm}$ in an ELISA reader. The percent positivity (PP) values were calculated for the samples using the following formula:

Sample \% P (PP) $=\frac{\text { O.D } \mathrm{Dample}-\mathrm{O} . \mathrm{D}_{\mathrm{NC}}}{-\mathrm{OD}_{\mathrm{PC}}-\mathrm{O} . \mathrm{D}_{\mathrm{NC}}}$ O.D $\cdot D_{\text {Sample }}=$ Mean Optical Density of Sample.
O.D $D_{\mathrm{NC}}=$ Mean Optical Density of Negative Control.

O. $D_{\mathrm{PC}}=$ Mean Optical Density of Positive Control.

The Percent Positivity of positive control was considered as $100 \%$. The samples with PP of more than equal to cut off of $15 \%$ were considered as positive and samples having PP below $15 \%$ were considered negative.

\section{Results and Discussion}

\section{IS900 PCR}

Among 128 milk samples, no sample was detected as positive for Mycobacterium avium subsp. paratuberculosis.

\section{IS900MAP TaqMan Real-time PCR assay}

IS900 TaqMan assay measures the amount of target IS900 DNA produced during each cycle of an amplification reaction in a realtime format.

Thus, the system is able to quantify the amount of target DNA in contrast to the conventional PCR, which measures only the end-point values with qualitative results. $\mathrm{C}_{\mathrm{T}}$ values between 20 and 33 were considered positive. In all the milk samples, $C_{T}$ values were greater than 40 and hence were detected as negative for Mycobacterium avium subsp. paratuberculosis.

\section{ELISA}

Seven out of 128 milk samples (5.46\%) were detected positive for MAP by ELISA (Figure 1). The percent positivity ranged from $20 \%$ to $100 \%$ (Table 1). The percent positivity of > $15 \%$ was considered as positive sample and that of positive control was considered as $100 \%$. 
Table.1 The percent positivity of the suspected samples detected by ELISA

\begin{tabular}{|c|c|c|c|}
\hline Animal No. & Percent Positivity by ELISA & IS900 PCR & Real time PCR \\
\hline 1 & 68.91 & Negative & Negative \\
\hline 2 & 64.65 & Negative & Negative \\
\hline 3 & 33.85 & Negative & Negative \\
\hline 4 & 20.00 & Negative & Negative \\
\hline 5 & 122.14 & Negative & Negative \\
\hline 6 & 74.52 & Negative & Negative \\
\hline 7 & 61.64 & Negative & Negative \\
\hline
\end{tabular}

Fig.1 An ELISA Plate showing colour development in positive samples

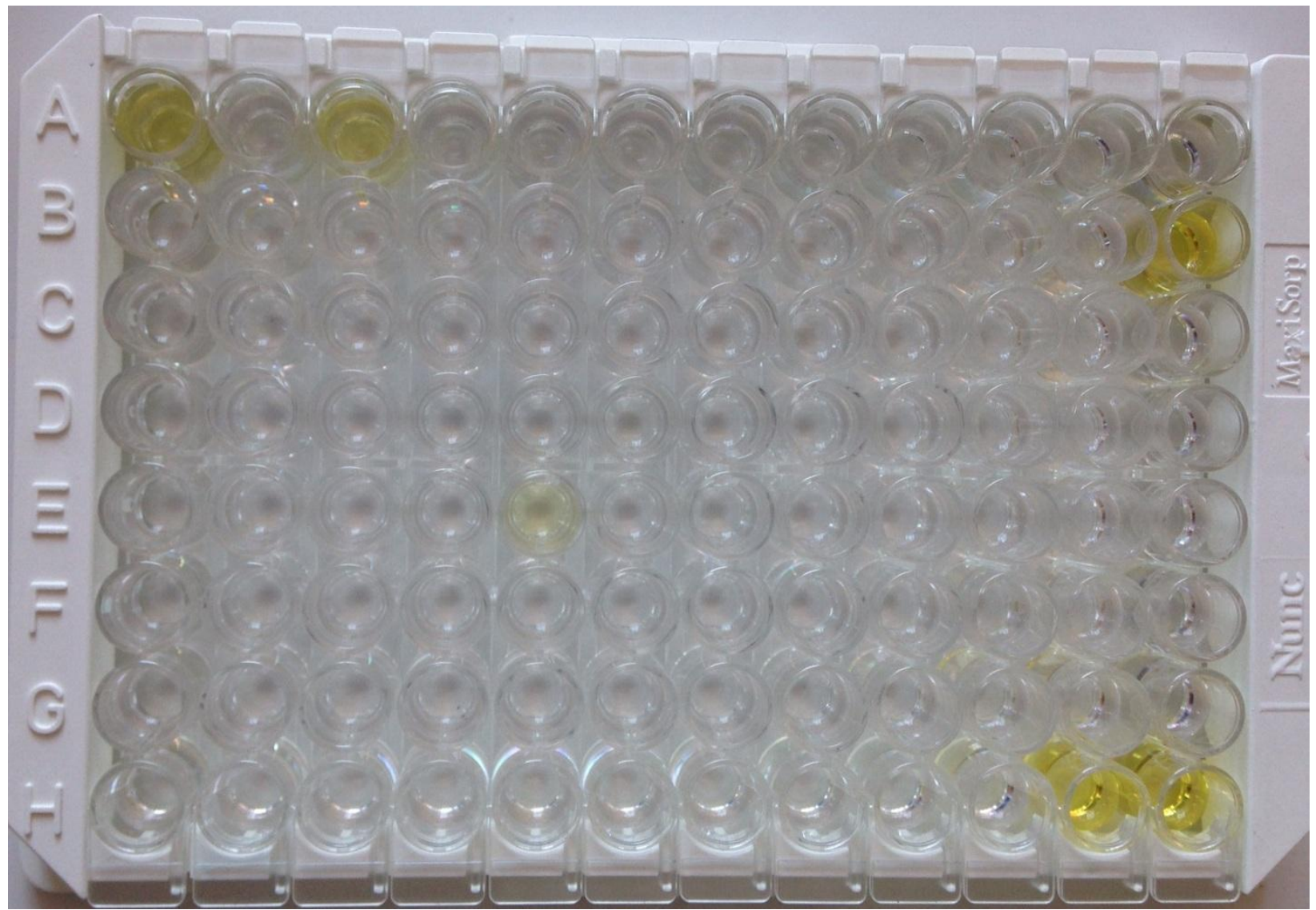

Mycobacterium avium subsp. paratuberculosis is a recognized pathogen that affects many species of ruminant and non-ruminant animals (Stabel et al., 2004). MAP infection of domestic-food-producing animals is associated with significant economic loss to the livestock industry worldwide. At present, several new preventive strategies have been employed to restrict the spread of MAP among animals and subsequently limit the economic losses. This is because of the relatively low sensitivities of the currently available tests, which fail to detect subclinical (first and second stage) MAP-infected animals (Fecteau and Whitlock 2010). Infected animals exhibiting clinical or subclinical infection sheds MAP bacteria in both milk and faeces. 
Detectable levels of MAP have been found in milk from both clinically infected cattle (Giese and Ahrens 2000) and asymptomatic carriers (Streeter et al., 1995). Sweeney et al., in 1994 found that MAP is shed into milk by $12 \%$ of subclinically infected cows in a concentration of 2 to $8 \mathrm{CFU}$ per $50 \mathrm{ml}$ milk. Serology and faecal culture, however, are the most commonly used tests in the field (Stabel et al., 2002). Efficiency of PCR for paratuberculosis is the challenge faced in extracting DNA from MAP, which can be enhanced by selecting the most accurate methodology for the purpose of testing. Two specific challenges faced during DNA extraction from MAP include inhibitors present in the sample that can hinder DNA amplification and also the thick, waxy cell wall of MAP, which requires more intense lysis techniques, such as bead-beating to extract the DNA. By using a sequence unique for MAP, specificity of real-time PCR is comparable to culture techniques and can reach 100\% (Leite et al., 2013). However, sensitivity of real-time PCR for MAP is dependent upon additional factors including technique, bacterial concentration within the sample, bacterial loss during processing or storage, and reference standard accuracy (Bolske and Herthnek, 2010).

The main type of immunological test that is widely available and commonly used is the enzyme linked immunosorbant assay (ELISA), which detects an optical density in serum (Hardin and Thorne, 1996) or milk (Kudhal, 2004) that correlates with an antibody response to MAP. The ELISAs have been desirable tests to use because of their ease of sample collection (blood or milk), rapid test results (within a week), and relatively low cost. The sensitivity of ELISA for detection of high shedders was $>90 \%$ both for individual milk and serum samples (Van Weering et al., 2007). Specificity for ELISA has been shown to be less than $100 \%$ depending on the kit and method (Nielsen and Toft, 2008). Therefore, ELISA results need to be evaluated in light of the purpose for testing (such as detection or screening) and should be followed up with direct detection methods for absolute confirmation (Collins 2011). The presence of antibodies can be predictive of higher risk for MAP shedding (Lavers et al., 2013). Detection of antibodies using the ELISA test is the most frequently used method for JD diagnosing. However, the concentration of antibodies in milk is related not only to the level of antibodies in serum but also the milk yield, lactation period and even the calving number (Sweeney et al., 2006). Studies so far conducted milk sample testing with ELISA test has shown $12 \%$ more positive results than the tests in the serum from the same animals. A recent study in Ontario (Hendrick et al., 2005) reported only moderate agreement between serum and milk ELISAs, and the milk ELISA detected 12\% fewer infected cows than did the serum ELISA. These findings make biological sense considering that antibody concentrations in milk depend not only on levels in serum, but also on milk production, parity and days in milk (Nielson et al., 2002). The added variability in antibody levels in milk relative to serum makes interpretation of results from milk ELISA even more challenging than those from serum ELISA, which have inherent laboratory variability (Nielsen, 2002). Further research may identify a role for the milk ELISA as a practical method of monitoring MAP infection at the herd level or instigating interest in controlling JD.

The presence of MAP specific antibodies in the milk is an indication of prior exposure of the animal to the organism.

\section{Acknowledgement}

The authors are thankful to the Director of Research, GADVASU, Ludhiana for the 
funding under RKVY Scheme on "Evaluation of mainly molecular diagnostic tests for the development of suitable strategy in diagnosis of Mycobacterial infections (Bovine Tuberculosis and Johne's Diseases) in cattle and buffaloes agro climatic zones of Punjab.

\section{References}

Ayele, W.Y., Machackova, M. and Pavlik, I. 2001. The transmission and impact of paratuberculosis infection in domestic and wild ruminants. Vet. Med-Czech., 46: 205-224.

Beard, P.M., Daniels, M.J. and Henderson, D. 2001. Paratuberculosis infection of nonruminant wildlife in Scotland. $J$. Clin. Microbiol., 39: 1517-1521.

Bolske, G. and Herthnek, D. 2010. Diagnosis of paratuberculosis by PCR. pp- 267283 in Paratuberculosis: Organism, Disease, Control. M. Behr and D. M. Collins, ed. CAB International, Cambridge, MA.

Collins, M. T. 2011. Diagnosis of Paratuberculosis. Vet. Clin. Food. Anim. 27: 581-591.

Collins, M.T. 1996. Diagnosis of paratuberculosis. Vet. Clin. North. Am. Food. Ani. Pract., 12: 357-371.

Fecteau, M.E. and Whitlock, R.H. 2010. Paratuberculosis in cattle. In Paratuberculosis: organism, disease, control. Edited by Behr MA, Collins DM. Oxfordshire, UK: CAB International, 144-156.

Gao, A., Mutharia, L., Raymond, M. and Odumeru, J. 2007. Improved template DNA preparation procedure for detection of Mycobacterium avium subsp. paratuberculosis in milk by PCR. J. Microbiol. Methods., 69: 417420.

Giese, S.B. and Ahrens, P. 2000. Detection of Mycobacterium avium subsp. paratuberculosis in milk from clinically affected cows by PCR and culture. Vet. Microbiol., 77: 291-297.

Hardin, L.E. and Thorne, J.G. 1996. Comparison of milk with serum ELISA for the detection of paratuberculosis in dairy cows. J. Am. Vet. Med. Assoc., 209: 120-122.

Hendrick, S.H., Duffield, T.E., Kelton, D.E., Leslie, K.E., Lissemore, K.D. and Archambault, M. 2005. Evaluation of enzyme-linked immunosorbent assays performed on milk and serum samples for detection of paratuberculosis in lactating dairy cows. J. Am. Vet. Med. Assoc., 226: 424-428

Hermon-Taylor, J., Bull, T.J., Sheridan, J.M., Cheng,., Stellakis, M.L. and Sumar, N. 2000. Causation of Crohn's disease by Mycobacterium avium subspecies paratuberculosis. Can. J. Gastroenterol., 14: 521-539.

Hori-Oshima, S., Campos-Barba, L.A., Moreno-Rosales, J.F., RenteriaEvangelista, T.B., Lopez-Valencia, G., Dela Mora, A. and Corral-Madriod, A. 2007. Seroprevalence of bovine paratuberculosis in dairy cattle herds in the Mexico-U.S. border area in Baja California, Mexico. In: Proceedings of the nineth ICP, Tsukuba, Japan, 71.

Kalis, C.H.J., Collins, M.T., Hesselink, J.W. and Barkema, H.W. 2003. Specificity of two tests for the early diagnosis of bovine paratuberculosis based on cellmediated immunity: the Johnin skin test and the gamma interferon assay. Vet. Microbiol., 97: 73-86.

Kudahl, A., Nielsen, S.S. and Sorensen, J.T. 2004. Relationship between antibodies against Mycobacterium avium subsp. paratuberculosis in milk and shape of lactation curves. Prev. Vet. Med., 62: 119-134.

Lavers, C. J., McKenna, S. L. B., Dohoo, I. R., Barkema, H. W. and Keefe, G. P. 2013. Evaluation of environmental fecal 
culture for Mycobacterium avium subspecies paratuberculosis detection in dairy herds and association with apparent within-herd prevalence. Can. Vet. J., 54: 1053-1060.

Leite, F. L., Stokes, K. D., Robbe-Austerman, S. and Stabel, J. R. 2013. Comparison of fecal DNA extraction kits for the detection of Mycobacterium avium subsp. paratuberculosis by polymerase chain reaction. J. Vet. Diagn. Invest., 25: 27-34.

Manning, E.J. and Collins, M.T. 2001. Mycobacterium avium subsp. paratuberculosis: pathogen, pathogenesis and diagnosis. Rev. Sci. Tech., 20: 133-150.

Nielsen,S.S. 2002. Variance components of an enzyme-linked immunosorbent assay for detection of $\mathrm{IgG}$ antibodies in milk samples to Mycobacterium avium subspecies paratuberculosis in dairy cattle. J. Vet. Med. 49: 384-387.

Nielsen, S. S. and N. Toft. 2008. Ante mortem diagnosis of paratuberculosis: A review of accuracies of ELISA, interferon- $\gamma$ assay and faecal culture techniques. Vet. Microbiol., 129: 217235.

Nielsen, S.S. 2010. Immune-based diagnosis of paratuberculosis. Pp-284-293 in Paratuberculosis: Organism, Disease, Control. M. Behr and D. M. Collins, ed. CAB International, Cambridge, MA.

Nielsen, S.S. and Toft, N. 2009. A review of prevalences of paratuberculosis in farmed animals in Europe. Prev. Vet. Med., 88: 1-14.

Nielsen, S.S., Enevoldsen, C. and Grohn, Y.T. 2002. The Mycobacterium avium subsp. paratuberculosis ELISA response by parity and stage of lactation. Prev. Vet. Med., 54: 1-10.

OIE Manual. Manual of standards for diagnostic test and vaccines: Paratuberculosis (Johne's disease)
Section 2.2, Chapter 2.2.6, OIE, Paris, France, 2004.

OIE Terrestrial Manual. Paratuberculosis (Johne's disease) Section 2.1, Chapter 2.1.11, OIE, Paris, France, 2008.

Ott, S.L., Wells, S.J. and Wagner, B.A. 1999. Herdlevel economic losses associated with Johne's disease on US dairy operations. Prev. Vet. Med., 40: 179192.

Ridge, S.E., Heuer, C., Cogger, N., Heck, A., Moor, S., Baker, I.M. and Vaughan, S. 2010. Herd management practices and transmission of Johne's disease within infected dairy herds in Victoria, Australia. Prev. Vet. Med., 95: 186-197.

Singh, S.V., Singh, A.V., Singh, R., Sharma, S., Shukla, N., Misra, S., Singh, P.K., Sohal, J.S., Kumar, H., Patil, P.K., Misra, P. and Sandhu, K.S. 2008. Seroprevalence of bovine Johne's disease in buffaloes and cattle population of North India using indigenous ELISA kit based on native Mycobacterium avium subspecies paratuberculosis "Bison type" genotype of goat origin. Comp. Immunl. Microbiol. Infect. Dis., 31: 419-433.

Stabel, J.R., Bosworth, T.L., Kirkbride, T.A., Forde, R.L. and Whitlock, R.H. 2004. A simple, rapid and effective method for the extraction of Mycobacterium paratuberculosis DNA from fecal samples for polymerase chain reaction. J. Vet. Diagn Invest., 16: 22-30.

Stabel, J.R., Wells, S.J. and Wagner, B.A. 2002. Relationships between fecal culture, ELISA and bulk tank milk test results for Johne's disease in US dairy herds. J. Dairy Sci., 85: 525-531.

Streeter, R.N., Hoffsis, G.F., Bech-Nielsen, S., Shulaw, W.P. and Rings, D.M. 1995. Isolation of Mycobacterium paratuberculosis from colostrums and milk of subclinically infected cows. Am. J. Vet.Res., 56: 1322-24. 
Sweeney, R.W., Whitlock, R.H., Buckley, C.L., Spencer, P., Rosenberger, A.E. and Hutchinson, L.J. 1994. Diagnosis of paratuberculosis in dairy cattle, using enzyme-linked immunosorbent assay for detection of antibodies against Mycobacterium paratuberculosis in milk. Am. J. Vet. Res., 55: 905-909.

Sweeney, R.W., Whitlock, R.H., McAdams, S. and Fyock, T. 2006. Longitudinal study of ELISA seroreactivity to Mycobacterium avium subsp. paratuberculosis in infected cattle and culture-negative herd mates. J. Vet. Diagn. Invest, 18: 2-6.

Vander Giessen, J.W.B., Haring, R.M. and Vauclare, E. 1992. Evaluation of the abilities of three diagnostic tests based on the polymerase chain reaction to detect Mycobacterium paratuberculosis in cattle: Application in a control program. J. Clin. Microbiol., 30: 12161219.

VanWeering, H., VanSchaik, G., Vander Meulen, G., Waal, M., Franken, P. and Van Maanen, K. 2007. Diagnostic performance of the Pourquier ELISA for detection of antibodies against Mycobacterium avium subspecies paratuberculosis in individual milk and bulk milk samples of dairy herds. Vet. Microbiol, 15: 49-58.

Whitlock, R.H. 2009. Johne's disease. Pages 881-887 in Large Animal Internal Medicine, fourth edn, B. P. Smith, ed. Mosby Elsevier, St. Louis, MO.

\section{How to cite this article:}

Deepti Narang, Gagandeep Kaur, Sumiyah Rasool, Mudit Chandra and Sharma, N.S. 2017. Milk ELISA in Diagnosing Paratuberculosis in Cattle and Buffaloes. Int.J.Curr.Microbiol.App.Sci. 6(11): 3470-3477. doi: https://doi.org/10.20546/ijcmas.2017.611.408 